\title{
The Role of parC, parE, and qnrB Genes in Ciprofloxacin-Resistant Escherichia coli Isolates from Urinary Tract Infections
}

\author{
Marjan Iranzad, ${ }^{1}$ and Mojdeh Hakemi-Vala ${ }^{2,3{ }^{*}}$ \\ ${ }^{1}$ Department of Microbiology, Rasht Branch, Islamic Azad University, Rasht, IR Iran \\ ${ }^{2}$ Infectious Disease and Tropical Medicine Research Center, Shahid Beheshti University of Medical Sciences (SBMU), Tehran, IR Iran \\ ${ }^{3}$ Department of Microbiology, Medical School, Shahid Beheshti University of Medical Sciences (SBMU), Tehran, IR Iran \\ "Corresponding author: Mojdeh Hakemi-Vala, Kodakyar St, Daneshjo Blvd, Velenjak, Tehran, Iran. Tel: +98-2123872556, E-mail: m.hakemi@sbmu.ac.ir
}

Received 2016 August 14; Revised 2016 November 03; Accepted 2016 December 03.

\begin{abstract}
Background: Urinary tract infections (UTIs) are the most common infectious diseases, imposing great costs on the community. Escherichia coli (E. coli) is the most frequent pathogen of UTIs. On the other hand, ciprofloxacin is a wide-spectrum antibiotic, used for the treatment of persistent and recurrent UTIs. Nevertheless, the increasing chromosomal or plasmid resistance of this bacterium has become a major health problem. In this study, we aimed to determine the role of parC, parE, and qnrB genes in ciprofloxacinresistant $E$. coli isolates from urine samples of patients suffering from UTI.

Methods: Midstream urine samples of patients suffering from UTIs, who were referred to Imam Khomeini hospital, Tehran, Iran during May-October 2014, were collected and evaluated for E. coli isolates. All the isolates were subjected to antimicrobial susceptibility testing (AST) by the standard disk diffusion method, according to the clinical and laboratory standards institute (CLSI) 2014 guidelines. The role of chromosomal genes, parC and parE, in addition to plasmid gene qnrB, was determined by polymerase chain reaction (PCR) method and further sequencing.

Results: Among 124 patients, $64.5 \%$ of UTI cases were positive for E. coli. Based on the AST results, $77.5 \%$ of the isolates were resistant to ciprofloxacin. The size of PCR bands was $265 \mathrm{bp}$ for parE, $389 \mathrm{bp}$ for parC, and $268 \mathrm{bp}$ for qnrB genes. Also, the frequency of intact genes among ciprofloxacin-resistant isolates was $90.9 \%$ for parC, $97.67 \%$ for $p a r E$, and $0 \%$ for $q n r B$ genes. Some mutations were detected in the chromosomal genes after sequence analysis.

Conclusions: This study showed the important role of mutated chromosomal resistant genes in comparison with plasmid genes in the emergence of ciprofloxacin-resistant E. coli strains.
\end{abstract}

Keywords: Urinary Tract Infections, Ciprofloxacin, Drug Resistance, Escherichia coli

\section{Background}

Urinary tract infections (UTIs) are one of the most common infectious diseases, affecting a large number of patients worldwide. UTIs increase the risk of morbidity and mortality among patients and impose great health costs on the affected patients and the community $(1,2)$. The incidence of UTIs varies with respect to age, sex, genetics, and underlying diseases (3).

Risk factors associated with UTIs are categorized into host factors, host behaviors, and bacterial characteristics, which expose the host to potential uropathogens, enhance colonization, or make the host respond to colonization (4). Colonized bacteria in the bowel and vaginal cavity can be easily transferred to women's urinary tract, given the short distance, making sexually active women more susceptible to UTIs (4).

Escherichia coli (E. coli), a Gram-negative bacterium consisting of various subtypes, is the most common uropathogen causing UTIs (namely uropathogenic E. coli) (5-7). Therefore, treatment of UTIs is dependent on the administration of appropriate antibiotics. However, high resistance of $E$. coli to antibiotics has become a major treatment problem (8). Studies have reported the resistance of E. coli to various antibiotics, including $\beta$-lactam, cephalosporins, gentamicin, and fluoroquinolones $(9,10)$.

The high prevalence of resistance to trimethoprimsulfamethoxazole (TMP/SMX) has led to the administration of fluoroquinolones, which are highly effective and convenient for persistent and recurrent UTIs caused by E. coli (11). However, previous review studies have reported an increasing trend in resistance to ciprofloxacin in recent years (12).

The mechanisms underlying this resistance in E. coli have been investigated in the literature. In 1990, Kato et al. first introduced topoisomerase IV, a homolog of DNA gyrase, composing of two parts, ie, parE and parC in E. coli (13).

Other studies later posited that quinolones stabilize the complex between DNA and DNA gyrase or topoisomerase IV through formation of reversible drug-enzymeDNA complexes and inhibiting the progression of polymerase and DNA replications $(14,15)$. Therefore, mutations 
in parE and parC genes in E. coli strains could be involved in resistance to quinolones $(16,17)$. In addition, qnrB gene in interaction with E. coli DNA gyrase has been proposed as plasmid-encoded resistance to quinolones (18-21).

In general, better identification of the associated genes can help researchers and clinicians improve the treatment of various infections, including UTIs, with ciprofloxacin of fluoroquinolones. With this background in mind, we aimed to determine the role of parC, parE, and qnrB genes in ciprofloxacin-resistant E. coli isolates from urine samples of patients suffering from UTI.

\section{Methods}

\subsection{Sample Size}

The sample size was calculated, based on the frequency of $E$. coli isolates for UTIs, using the following formula: $\mathrm{N}=$ $(1.96)^{2}(0.7)(0.3) /(0.1)^{2}=80.6 \sim 80$

\subsection{Study Design and Bacterial Isolation}

A total of $80 \mathrm{E}$. coli isolates from urine samples were collected from outpatients and inpatients, who were referred to Imam Khomeini Hospital for presumptive UTI during May-October 2014. All 124 urine samples were collected by midstream clean-catch method in sterile containers. Bacterial isolation was performed, based on standard bacteriological tests, such as catalase and oxidase tests, using MacConkey agar, triple sugar iron agar, and IMViC tests.

Patients were divided into adult (above 18 years) and young (below 17.9 years) groups. Also, the sex of the patients and the hospital wards were recorded. All E. coli isolates were maintained in tris-buffered saline culture, containing $15 \%$ glycerol at $-70^{\circ} \mathrm{C}$ until they were transferred to the Research Laboratory of Shahid Beheshti University of Medical Sciences, Tehran, Iran for further analysis.

\subsection{Antibiotic Sensitivity Test (AST)}

The resistance/sensitivity of the isolates to 20 common antibiotics was investigated by standard disk diffusion technique (Kirby-Bauer method), according to the clinical and laboratory standards institute (CLSI) 2014 guidelines; all disks were provided from Rosco Company (Denmark). The antibiotics used for AST included ceftriaxone, piperacillin, amikacin, gentamicin, ciprofloxacin, amoxicillin, cefazolin, aztreonam, cefepime, trimethoprim/sulfamethoxazole, nitrofurantoin, chloramphenicol, imipenem, meropenem, ertapenem, ampicillin, ofloxacin, norfloxacin, tetracycline, and cefixime.

A bacterial lawn was prepared on the Mueller-Hinton agar, using a sterile cotton swab continuously. For this purpose, bacterial suspensions were prepared with turbidity equal to 0.5 MacFarland $\left(1.5 \times 10^{8} \mathrm{CFU} / \mathrm{mL}\right)$. Afterwards, antibiotic disks were placed on the plate by sterile forceps. The plates were incubated at $37^{\circ} \mathrm{C}$ for 18 - 24 hours. Then, the diameter of the inhibition zone around the disks was measured by a millimeter ruler. The results were compared to the standard table and were reported as sensitive, intermediate, or resistant.

\subsection{Minimum Inhibitory Concentration (MIC) of Ciprofloxacin by E-Test Method}

Bacteria were considered resistant to the drug when there was no inhibition zone around them. The ciprofloxacin-resistant isolates in AST were assessed in terms of MIC by E-test strip method (Liofichem, Denmark). According to CLSI 2014 guidelines, MIC $\leq 1$ was considered sensitive, MIC $\geq 4$ was regarded as resistant, and MIC $=2$ was considered intermediate.

\subsection{DNA Extraction, PCR Method, and Sequencing}

Chromosomal DNA of the bacteria was extracted by boiling method for further PCR of chromosomal parC and parE genes. The GeneJET Plasmid Miniprep kit (Thermo Scientific, Lithuania) was used to extract plasmid for further PCR analysis of qnrB gene. The Master Mix (Thermo Scientific, Lithuania) was used for the PCR mixture. Also, distilled water and E. coli ATCC 25922 were used as the negative and positive controls, respectively. The list of primers, PCR programs, and PCR products is mentioned in Tables 1 and 2.

Table 1. The Sequence of Primers Used in the Present Study

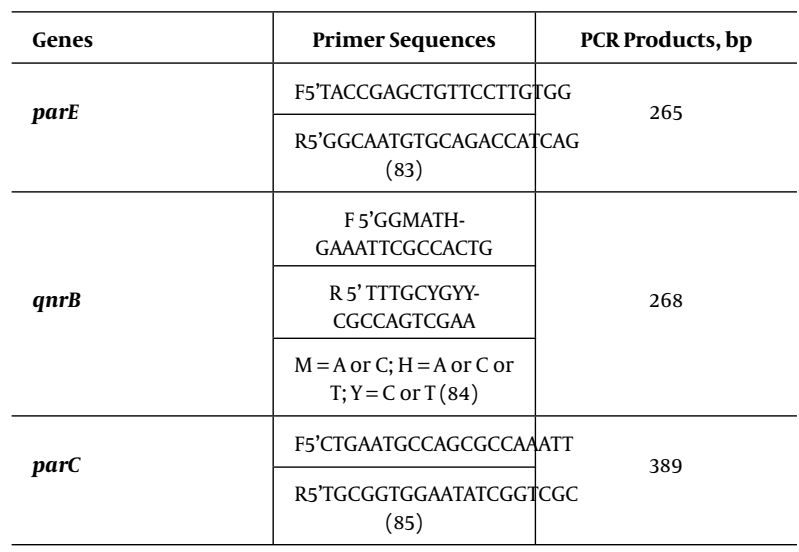

PCR products of the studied genes were determined after electrophoresis on 1.5\% agarose gel and visualized under UV radiation for gel documentation. Further sequencing was performed by Bioneer Company (Korea). The nucleotide sequences were analyzed with the Chromas 1.45 
Table 2. The PCR Programs (35 Cycles)

\begin{tabular}{lccc}
\hline Stages & $\begin{array}{c}\text { Temperature, } \\
{ }^{\circ} \mathrm{C}\end{array}$ & $\begin{array}{c}\text { Time (for parC } \\
\text { and parE) }\end{array}$ & $\begin{array}{c}\text { Time for qnrB } \\
\text { Gene, } \text { min }\end{array}$ \\
\hline $\begin{array}{l}\text { Primary } \\
\text { denaturation }\end{array}$ & 95 & $5 \mathrm{~min}$ & 10 \\
$\begin{array}{l}\text { Denaturation } \\
\text { Primer } \\
\text { coupling }\end{array}$ & 95 & $40 \mathrm{~s}$ & 1 \\
\hline $\begin{array}{l}\text { Polymerization } \\
\text { Final polymer- }\end{array}$ & 56.2 & $40 \mathrm{~s}$ & 1 \\
\hline ization & 72 & $40 \mathrm{~s}$ & 1 \\
\hline
\end{tabular}

software and BLAST in NCBI. Afterwards, the genes were submitted to GenBank.

\subsection{Statistical Analysis}

In this descriptive-application study, the results are presented as frequency (percentage) for categorical variables with $95 \%$ confidence intervals ( $95 \% \mathrm{CI}$ ). For the statistical analysis, SPSS version 21.0 (SPSS Inc., Chicago, IL) was used. $\mathrm{P}$ value $\leq 0.05$ was considered statistically significant.

\section{Results}

Among 80 E. coli strains, isolated from 124 urine samples $(64.5 \%), 79 \%$ were from adults and $21 \%$ were from children. In terms of sex, $51 \%$ of the subjects were female, $28 \%$ were male, $13 \%$ were girls, and $8 \%$ were boys. Most of the urine samples were collected from inpatients: $35 \%$ from the gynecology ward, 15\% from the urology ward, $14 \%$ from the neurology ward, and 10\% from the miscellaneous wards. Also, 25\% of the samples were collected from the outpatients.

The resistance level of $E$. coli to the studied antibiotics is demonstrated in Table 3. As shown, there was a high rate of resistance to piperacillin, ampicillin (85\% and $83.8 \%$, respectively), TMP/SMX, ciprofloxacin, and tetracycline $(78.7 \%, 77.5 \%$, and 75\%, respectively). Also, $100 \%$ sensitivity to ertapenem, meropenem, and imipenem and $98.7 \%$ sensitivity to nitrofurantoin were detected.

The intact genes of parC and parE were detected in 92.5\% and $91.3 \%$ of the samples, respectively; the frequency of qnrB gene was negative in all the isolates. The size of PCR bands was $265 \mathrm{bp}$ for parE, $389 \mathrm{bp}$ for parC, and $268 \mathrm{bp}$ for qnrB genes, as demonstrated in Figure 1. Comparison of the sequence of the extracted proteins with the protein sequence of ATCC 25922 is demonstrated in Figures 2 and 3.
Table 3. The Frequency of E. coli Resistance to the Studied Antibiotics ${ }^{\mathrm{a}}$

\begin{tabular}{|c|c|c|c|}
\hline Antibiotics & Resistant & Intermediate & Sensitive \\
\hline Piperacillin, $100 \mu \mathrm{g}$ & 85 & 2.5 & 12.5 \\
\hline Ampicillin, $10 \mu \mathrm{g}$ & 16.2 & 27.5 & 56.3 \\
\hline $\begin{array}{l}\text { Amoxicillin-clavulanic, } \\
20 / 10 \mu \mathrm{g}\end{array}$ & 77 & - & 23 \\
\hline Cefazolin, $30 \mu \mathrm{g}$ & 73.7 & 2.5 & 23.8 \\
\hline Norfloxacin, $10 \mu \mathrm{g}$ & 71.2 & 0 & 28.8 \\
\hline Ceftriaxone, $30 \mu \mathrm{g}$ & 72.5 & 1.3 & 26.2 \\
\hline Cefepime, $30 \mu \mathrm{g}$ & 42.5 & 21.3 & 36.2 \\
\hline Gentamicin, $10 \mu \mathrm{g}$ & 62.5 & 25 & 35 \\
\hline Amikacin, $30 \mu \mathrm{g}$ & 11.4 & 5.1 & 83.5 \\
\hline $\begin{array}{l}\text { Trimethoprim/sulfamethoxazı } \\
\text { (SXT),1.25/23.75 } \mu \mathrm{g}\end{array}$ & 78.7 & 0 & 21.3 \\
\hline Ciprofloxacin, $5 \mu \mathrm{g}$ & 77.5 & 3.8 & 18.7 \\
\hline Aztreonam, $30 \mu \mathbf{g}$ & 68.7 & 3.8 & 27.5 \\
\hline Nitrofurantoin, $300 \mu \mathrm{g}$ & 1.3 & 0 & 98.7 \\
\hline Ertapenem, $10 \mu \mathrm{g}$ & 0 & 0 & 100 \\
\hline Meropenem, $10 \mu \mathrm{g}$ & 0 & 0 & 100 \\
\hline Imipenem, $10 \mu \mathrm{g}$ & 0 & 0 & 100 \\
\hline Cefixime, $5 \mu \mathrm{g}$ & 12.5 & 6.2 & 81.3 \\
\hline Chloramphenicol, $30 \mu \mathrm{g}$ & 22.5 & 5 & 72.5 \\
\hline Tetracycline, $30 \mu \mathrm{g}$ & 75 & 0 & 25 \\
\hline Ofloxacin, $5 \mu \mathrm{g}$ & 67.4 & 0 & 32.6 \\
\hline Ampicillin, $10 \mu \mathrm{g}$ & 83.8 & 6.2 & 10 \\
\hline
\end{tabular}

${ }^{\mathrm{a}}$ Values are expressed as \%.

As observed, there was a change in the nucleotide sequence of ParE at 1316 (C to A), 1321 (A to T), 1360 (G to C), 1381 ( $\mathrm{G}$ to $\mathrm{C}$ ), and 1480 (C to T) and at 461 (V to L), 466 (V to $\mathrm{G}$ ), 467 (A to $\mathrm{S}$ ), 469 ( $\mathrm{Q}$ to $\mathrm{H}$ ), and 484 ( $\mathrm{K}$ to $\mathrm{L}$ ) of the protein nucleotide. Further submission of parC and parE genes in NCBI GenBank was performed with accession numbers, KT454384.1 and KT454385.1, respectively.

\section{Discussion}

This study was performed on $80 \mathrm{E}$. coli isolates from inpatients and outpatients with UTIs, who were referred to Imam Khomeini Hospital, Tehran, Iran during MayOctober 2014. Based on the AST results, 77.5\% of the isolates were resistant to ciprofloxacin. In a study by Karlowsky et al. investigating a large number of urine samples, ciprofloxacin-resistant E. coli was reported in $10.8 \%$ of the samples (22). Also, a random investigation of 670 centers in the United States showed resistance to ciprofloxacin 


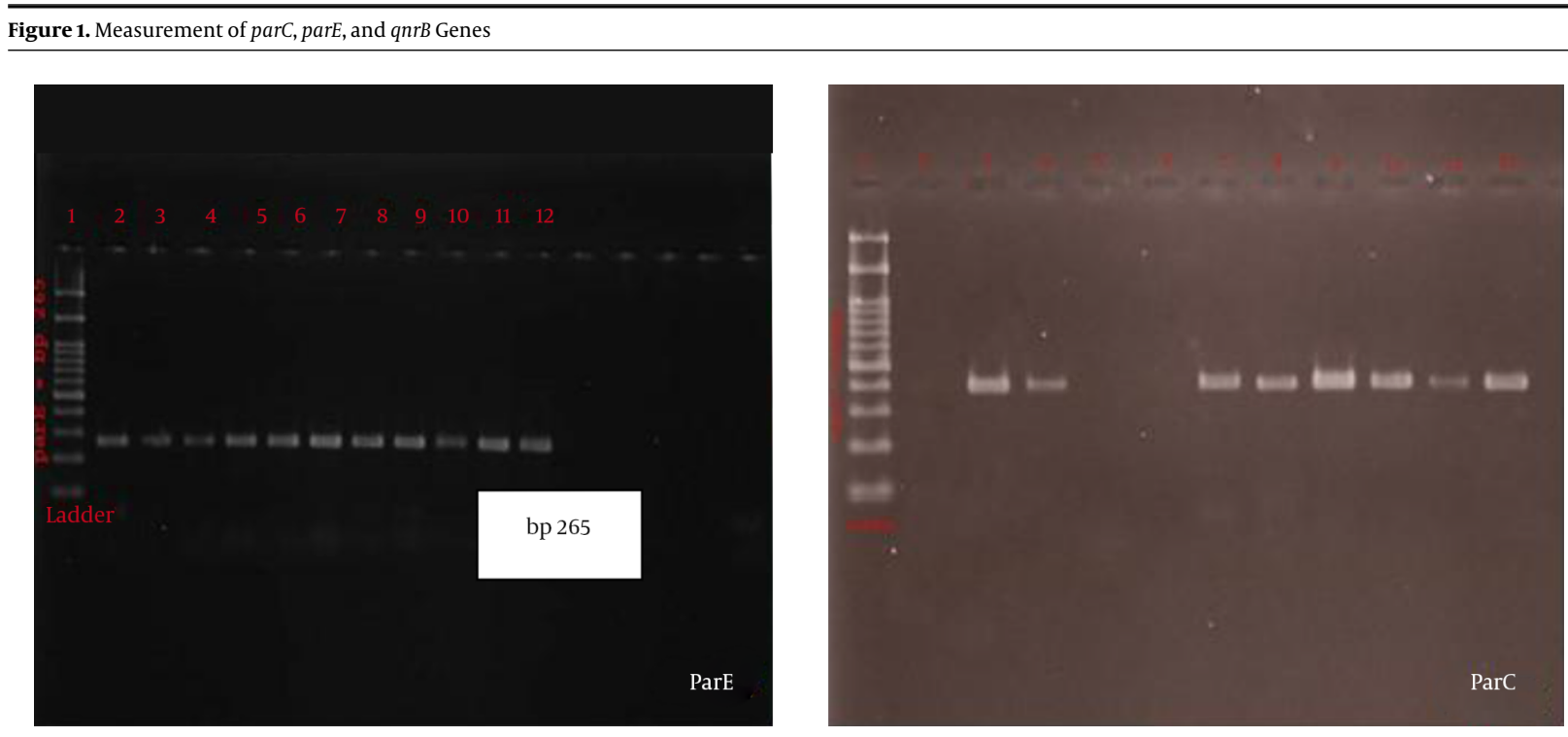

In parE, from left to right: lane 1, ladder $100 \mathrm{bp}$; lane 2, positive control; and lane 3, negative control. Lanes 3-12 were positive for a band of $265 \mathrm{bp}$. In parC, from left to right: lane1, 100 bp ladder; lane 2, negative control; and lane 3, positive control. The rest of the samples were positive and had a band of $365 \mathrm{bp}$.

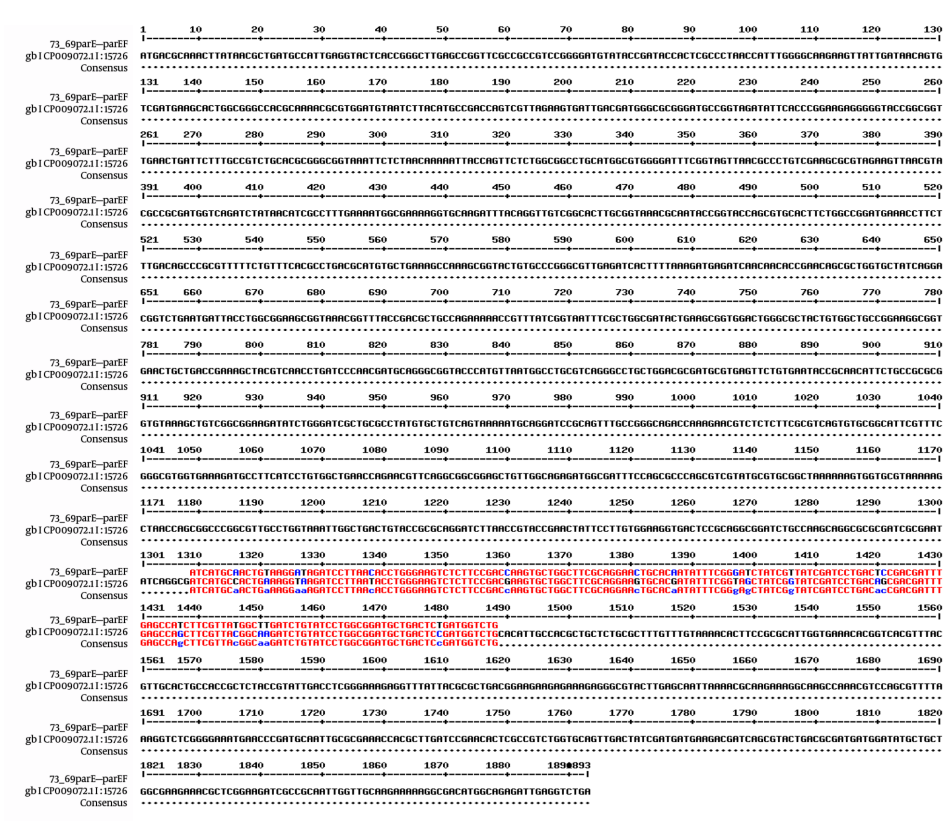

Figure 2. The Comparison of parC Sequence after Alignment with the Sequence of ATCC 25922

in less than $10 \%$ of the centers during 5 years (23).

Review studies have reported an increasing trend in fluoroquinolone-resistant E. coli (59\% to 95\%) (12). The resistance level in the present study was significantly higher than the mentioned reports, which indicates the high resistance level in the studied center. It can be concluded that ciprofloxacin is administered more frequently in Iran, compared to other countries.

According to a European study, the overall E. coli resistance to cephalosporin, nitrofurantoin, and gentamicin was less than $2 \%$, while higher resistance levels for ampicillin, TMP/SMX, amoxicillin/clavulanic acid, and ciprofloxacin $(0.5 \%-7.6 \%)$ were reported with an increasing trend in resistance to quinolones and trimethoprim 


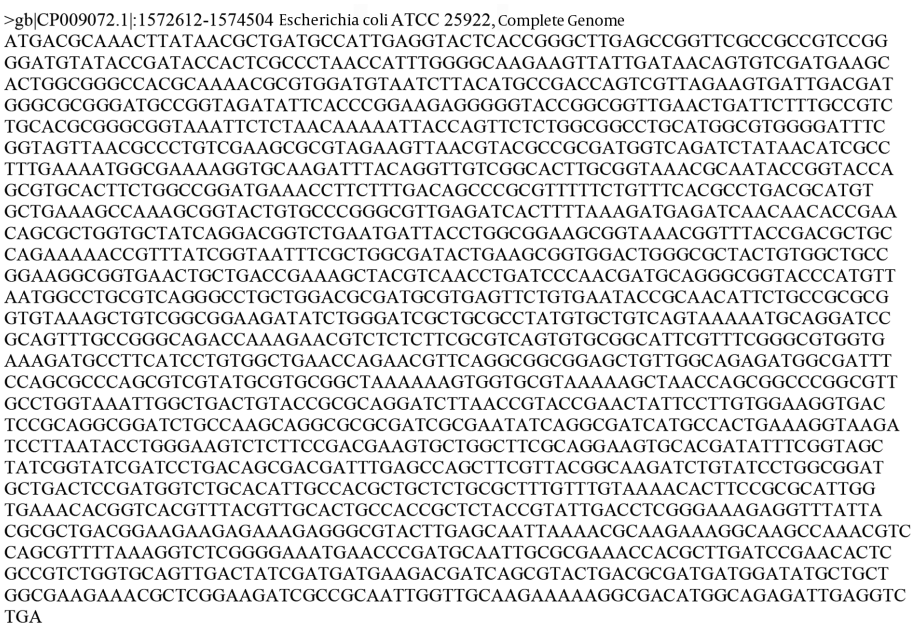

Figure 3. The Translated Protein of the Sequence of ATCC 25922 without Mutations in parE

from 1999 - 2000 to $2007-2008$ (9).

Similarly, in the present study, there was a high resistance level to ampicillin, TMP/SMX, and ciprofloxacin, whereas a low resistance level to nitrofurantoin was reported (although the rates were different). The discrepancy between studies performed in different countries can indicate that the prevalence of wide-spectrum antibiotic administration is more than needed in our country. Also, the increasing trend, suggested by the abovementioned studies, signifies that more caution should be taken with respect to the administration of the remaining sensitive antibiotics.

Khodadoost et al. from Iran reported 81.43\% and 62.13\% resistance rates to ampicillin and co-trimoxazole, respectively (24), which is close to the results of the present study. Mohajeri et al. also reported the resistance rate of $E$. coli isolates to ciprofloxacin as $43 \%$ (25), which was lower than the resistance rate reported in the present study (77.5\%). This could be attributed to the increasing emergence of resistant bacteria to wide-spectrum antibiotics.

Moreover, Mohajeri et al. introduced piperacillin and ampicillin as resistant antibiotics and imipenem and nitrofurantoin as sensitive drugs (25). This finding was in line with the results of the present study; however, minor differences in the resistance level to other antibiotics were observed. The increasing rate of resistance to such antibiotics is a warning for physicians regarding the indiscriminate administration of antibiotics, especially in Iran.

In a review article by Dallhoff, with reference to a study by Sahm et al. a 3.7\% resistance rate to ciprofloxacin was reported in UTI isolates of E. coli after 13 years of administration in the United States; this rate was twice higher in men than women and increased with age; they also reported a higher prevalence among inpatients (26). The mentioned study by Dallhoff was in line with the study by Karlowskey et al. from USA, which declared that the resistance of E. coli isolates to some antibiotics including ciprofloxacin is increasing. Also, ciprofloxacin was the only agent with a consistent increase in resistance from 0.7\% to 2.5\% during 1995 -2001(26).

Female dominance has been similarly reported in other studies (22). In the current research, women comprised $51 \%$ of adult patients and girls comprised $13 \%$ of the pediatric group of patients. The prevalence of E. coli in UTI in the present study was similar to previous research, reporting E. coli as the most prevalent pathogen causing UTIs $(5-7,27)$. In the present study, the frequency of the studied intact genes among ciprofloxacin-resistant isolates by PCR was as follows: $90.9 \%$ for parC, $97.67 \%$ for parE (intact chromosomal genes), and $0 \%$ for $q n r B$.

Linndgren et al. reported four mutations in parC (S80I, S80R, E84K, and E84G) and parE (I444F, S458T, D475E, and I529L) and detected mutations in parC among $83 \%$ of the resistant isolates. Also, none of the susceptible isolates showed mutations in parC gene. In addition, they postulated a significant genetic jump leading to a move from susceptibility to resistance (28). Various studies have similarly confirmed parC and parE mutations in quinoloneresistant bacterial isolates $(29,30)$.

In congruence with the present study, Warburg et al. identified a strong association between $\operatorname{aac}\left(6^{\prime}\right)-\mathrm{Ib}$-cr gene and ciprofloxacin resistance, defined by the CLSI criteria, and found no qnrB genes (31). They also showed that the interaction between resistance to $\beta$-lactamase and 
quinolones may result from the rise in the prescription of quinolones. Cattoir et al. also postulated that qnrB mutations do not play a role in resistance to $\beta$-lactamase (32).

However, some other studies introduced the role of qnrB mutations in quinolone-resistance (33-35). Also, some studies detected an interaction between qnrB and topoisomerase IV and reported an increase in the MIC of ciprofloxacin in the presence of $q n r B(20,21,36)$. This finding is inconsistent with the present results and demonstrated that the role of $q n r B$ gene in ciprofloxacin resistance is low. Our previous study showed that $39 \%$ of $E$. coli isolates from UTIs included the qnrA gene. Also, coexistence of qnrA gene in extended-spectrum ß-lactamasepositive E. coli isolates was detected (37).

The current study had some limitations. We only investigated the patients referring to one center for sample collection, which limited the sample size of the study. Due to the absence of qnrB gene in ciprofloxacin-resistant $E$. coli isolates, we investigated other similar genes and found $q n r A$ in $39 \%$ and $a a c\left(6^{\prime}\right)-I b-c r$ in $72 \%$ of resistant isolates (some of them are not published yet). Therefore, it is suggested that further studies consider the possible role of proton pump inhibitors in quinolone-resistance and investigate other wide-spectrum antibiotics.

In conclusion, the current study indicated that parC and parE gene mutations may play a more significant role in ciprofloxacin resistance in E. coli isolates, compared to other genes such as qnrB mutations. Also, it can be stated that AST must be performed according to CLSI protocols before prescribing any antibiotics in order to prevent resistance in some antibiotics to which $E$. coli is still sensitive.

\section{Acknowledgments}

The authors would like to thank the laboratory personnel of Imam Khomaini hospital of Tehran for their assistance during sample collection. Also, we express our gratitude to the Rasht Branch of Islamic Azad University, Rasht, Iran for their support.

\section{Footnote}

Funding/Support: The main study protocol was approved and supported by the Infectious Diseases and Tropical Medicine Research Center, Shahid Beheshti University of Medical Sciences (SBMU), Tehran, Iran.

\section{References}

1. Foxman B, Barlow R, D’Arcy H, Gillespie B, Sobel JD. Urinary tract infection: self-reported incidence and associated costs. Ann Epidemiol. 2000;10(8):509-15. [PubMed: 11118930].
2. Foxman B. Epidemiology of urinary tract infections: incidence, morbidity, and economic costs. Am J Med. 2002;113 Suppl 1A:5S-13S. [PubMed: 12113866].

3. Nicolle LE. Epidemiology of urinary tract infections. Clin Microbiol Newsl. 2002;24(18):135-40. doi: 10.1016/s0196-4399(02)80035-6.

4. Foxman B. Urinary tract infection syndromes: occurrence, recurrence, bacteriology, risk factors, and disease burden. Infect Dis Clin North Am. 2014;28(1):1-13. doi: 10.1016/j.idc.2013.09.003. [PubMed: 24484571].

5. Flores-Mireles AL, Walker JN, Caparon M, Hultgren SJ. Urinary tract in fections: epidemiology, mechanisms of infection and treatment options. Nat Rev Microbiol. 2015;13(5):269-84. doi: 10.1038/nrmicro3432. [PubMed: 25853778].

6. Kahlmeter G. The ECOSENS Project: a prospective, multinational, multicentre epidemiological survey of the prevalence and antimicrobial susceptibility of urinary tract pathogens-interim report.JAntimicrob Chemother. 2000;46(90001):15-22. doi:10.1093/jac/46.suppl_1.15.

7. Foxman B. The epidemiology of urinary tract infection. Nat Rev Urol. 2010;7(12):653-60. doi:10.1038/nrurol.2010.190. [PubMed: 21139641].

8. Chen YH, Ko WC, Hsueh PR. Emerging resistance problems and future perspectives in pharmacotherapy for complicated urinary tract infections. Expert Opin Pharmacother. 2013;14(5):587-96. doi: 10.1517/14656566.2013.778827. [PubMed: 23480061].

9. Kahlmeter G, Poulsen HO. Antimicrobial susceptibility of Escherichia coli from community-acquired urinary tract infections in Europe: the ECO.SENS study revisited. Int J Antimicrob Agents. 2012;39(1):45-51. doi: 10.1016/j.ijantimicag.2011.09.013. [PubMed: 22055529].

10. Azap OK, Arslan H, Serefhanoglu K, Colakoglu S, Erdogan H, Timurkaynak F, et al. Risk factors for extended-spectrum beta-lactamase positivity in uropathogenic Escherichia coli isolated from communityacquired urinary tract infections. Clin Microbiol Infect. 2010;16(2):14751. doi: 10.1111/j.1469-0691.2009.02941.x. [PubMed: 19689464].

11. Hooton TM. Fluoroquinolones and resistance in the treatment of uncomplicated urinary tract infection. Int J Antimicrob Agents. 2003;22 Suppl 2:65-72. [PubMed: 14527774].

12. Viray M, Linkin D, Maslow JN, Stieritz DD, Carson LS, Bilker WB, et al. Longitudinal trends in antimicrobial susceptibilities across longterm-care facilities: emergence of fluoroquinolone resistance. Infect Control Hosp Epidemiol. 2005;26(1):56-62. doi: 10.1086/502487. [PubMed: 15693409].

13. Kato J, Nishimura Y, Imamura R, Niki H, Hiraga S, Suzuki H. New topoisomerase essential for chromosome segregation in E. coli. Cell. 1990;63(2):393-404. [PubMed: 2170028].

14. Wentzell LM, Maxwell A. The complex of DNA gyrase and quinolone drugs on DNA forms a barrier to the T7 DNA polymerase replication complex.J Mol Biol. 2000;304(5):779-91. doi:10.1006/jmbi.2000.4266. [PubMed: 11124026].

15. Cheng G, Hao H, Dai M, Liu Z, Yuan Z. Antibacterial action of quinolones: from target to network. EurJ Med Chem. 2013;66:555-62. doi: 10.1016/j.ejmech.2013.01.057. [PubMed: 23528390].

16. Soussy CJ, Wolfson JS, Ng EY, Hooper DC. Limitations of plasmid complementation test for determination of quinolone resistance due to changes in the gyrase A protein and identification of conditional quinolone resistance locus. Antimicrob Agents Chemother. 1993;37(12):2588-92. [PubMed: 8109921].

17. Hsu YH, Chung MW, Li TK. Distribution of gyrase and topoisomerase IV on bacterial nucleoid: implications for nucleoid organization. $\mathrm{Nu}$ cleic Acids Res. 2006;34(10):3128-38. doi:10.1093/nar/gkl392. [PubMed: 16757578].

18. Tran JH, Jacoby GA. Mechanism of plasmid-mediated quinolone resistance. Proc Natl Acad Sci U S A. 2002;99(8):5638-42. doi: 10.1073/pnas.082092899. [PubMed:11943863].

19. Tran JH, Jacoby GA, Hooper DC. Interaction of the plasmidencoded quinolone resistance protein Qnr with Escherichia coli DNA gyrase. Antimicrob Agents Chemother. 2005;49(1):118-25. doi: 10.1128/AAC.49.1.118-125.2005. [PubMed: 15616284]. 
20. Tran JH, Jacoby GA, Hooper DC. Interaction of the plasmid-encoded quinolone resistance protein QnrA with Escherichia coli topoisomerase IV. Antimicrob Agents Chemother. 2005;49(7):3050-2. doi: 10.1128/AAC.49.7.3050-3052.2005. [PubMed:15980397].

21. Chen C, Villet R, Jacoby GA, Hooper DC. Functions of a GyrBA fusion protein and its interaction with QnrB and quinolones. Antimicrob Agents Chemother. 2015;59(11):7124-7. doi: 10.1128/AAC.01845-15. [PubMed: 26324265].

22. Karlowsky JA, Hoban DJ, Decorby MR, Laing NM, Zhanel GG Fluoroquinolone-resistant urinary isolates of Escherichia coli from outpatients are frequently multidrug resistant: results from the North American Urinary Tract Infection Collaborative Alliance-Quinolone Resistance study. Antimicrob Agents Chemother 2006;50(6):2251-4. doi:10.1128/AAC.00123-06. [PubMed: 16723598].

23. Diekema DJ, BootsMiller BJ, Vaughn TE, Woolson RF, Yankey JW, Ernst EJ, et al. Antimicrobial resistance trends and outbreak frequency in United States hospitals. Clin Infect Dis. 2004;38(1):78-85. doi 10.1086/380457. [PubMed: 14679451].

24. Khodadoost M, Akya A, Taha A, Mansour S, Adabagher S. The frequency of antibiotic resistance and ctx-m gene in escherichia coli isolated URMIA Med J. 2013;24(5):318-28.

25. Mohajeri P, Darfarin G, Farahani A. Genotyping of ESBL Producing Uropathogenic Escherichia coli in West of Iran. Int J Microbiol. 2014;2014:276941. doi: 10.1155/2014/276941. [PubMed: 24839441].

26. Dalhoff A. Global fluoroquinolone resistance epidemiology and implictions for clinical use. Interdiscip Perspect Infect Dis. 2012;2012:976273. doi: 10.1155/2012/976273. [PubMed: 23097666].

27. Manges AR, Johnson JR, Foxman B, O'Bryan TT, Fullerton KE, Riley LW. Widespread distribution of urinary tract infections caused by a multidrug-resistant Escherichia coli clonal group. $N$ Engl J Med. 2001;345(14):1007-13. doi: 10.1056/NEJMoa011265. [PubMed: 11586952].

28. Komp Lindgren P, Karlsson A, Hughes D. Mutation rate and evolution of fluoroquinolone resistance in Escherichia coli isolates from patients with urinary tract infections. Antimicrob Agents Chemother. 2003;47(10):3222-32. [PubMed: 14506034].

29. Breines DM, Ouabdesselam S, Ng EY, Tankovic J, Shah S, Soussy CJ, et al.
Quinolone resistance locus nfxD of Escherichia coli is a mutant allele of the parE gene encoding a subunit of topoisomerase IV. Antimicrob Agents Chemother. 1997;41(1):175-9. [PubMed: 8980775].

30. Heisig P. Genetic evidence for a role of parC mutations in development of high-level fluoroquinolone resistance in Escherichia coli. Antimicrob Agents Chemother. 1996;40(4):879-85. [PubMed: 8849244]

31. Warburg G, Korem M, Robicsek A, Engelstein D, Moses AE, Block C, et al. Changes in aac(6')-Ib-cr prevalence and fluoroquinolone resistance in nosocomial isolates of Escherichia coli collected from 1991 through 2005. Antimicrob Agents Chemother. 2009;53(3):1268-70. doi: 10.1128/AAC.01300-08. [PubMed: 19104026].

32. Cattoir V, Poirel L, Rotimi V, Soussy CJ, Nordmann P. Multiplex PCR for detection of plasmid-mediated quinolone resistance qnr genes in ESBL-producing enterobacterial isolates. $J$ Antimicrob Chemother. 2007;60(2):394-7. doi: 10.1093/jac/dkm204. [PubMed: 17561500].

33. Jacoby GA, Walsh KE, Mills DM, Walker VJ, Oh H, Robicsek A, et al. qnrB, another plasmid-mediated gene for quinolone resistance. Antimicrob Agents Chemother. 2006;50(4):1178-82. doi: 10.1128/AAC.50.4.11781182.2006. [PubMed: 16569827].

34. Robicsek A, Jacoby GA, Hooper DC. The worldwide emergence of plasmid-mediated quinolone resistance. Lancet Infect Dis. 2006;6(10):629-40. doi: 10.1016/S1473-3099(06)70599-0. [PubMed: 17008172].

35. Pakzad I, Ghafourian S, Taherikalani M, Sadeghifard N, Abtahi H, Rahbar M, et al. qnr Prevalence in Extended Spectrum Beta-lactamases (ESBLs) and None-ESBLs Producing Escherichia coli Isolated from Urinary Tract Infections in Central of Iran. Iran J Basic Med Sci. 2011;14(5):458-64. [PubMed: 23493061].

36. Kim ES, Chen C, Braun M, Kim HY, Okumura R, Wang Y, et al. Interactions between QnrB, QnrB mutants, and DNA gyrase. Antimicrob Agents Chemother. 2015;59(9):5413-9. doi: 10.1128/AAC.00771-15. [PubMed: 26100716].

37. Abdi S, Ranjbar R, Hakemi Vala M, Jonaidi N, Baghery Bejestany O, Baghery Bejestany F. Frequency of bla TEM, bla SHV, bla CTX-M, and qnrA Among Escherichia coli Isolated From Urinary Tract Infection. Arch Clin Infect Dis. 2014;9(1) doi: 10.5812/archcid.18690. 